\title{
Narratives of Ethnolinguistic Bordering: Cultural Encounters of Philippine Nikkeijin Workers in Aichi, Japan
}

\author{
RON BRIDGET VILOG
}

\begin{abstract}
By virtue of Japan's 1990 Immigration Policy, the so-called 'nikkeijin' or descendants of Japanese nationals who emigrated and settled in American and Southeast Asian territories before the Second World War, have been allowed to 'return' to their ancestral homeland (Japan). As a consequence, thousands of Brazilians, Peruvians and Filipino nikkeijin have been granted residency status by the Japanese government, with the clear expectation that they demonstrate cultural proximity leading to integration. Within their workplaces, nikkeijin encounter various cultures and ethnicities whose social positions and images are shaped by perceptions and expectations of the wider Japanese society. This article explores the formation and modification of ethnic boundaries, accompanied by the fragmentation of identities, during the experience of migration. The dynamics of 'identity bordering', based on regionalistic affiliations, are not only ignited by cultural stereotyping or ethnic attribution, they are also underpinned by the mechanism of power politics within the workplace. This study utilized the life history interviews of 60 third generation (sansei) and fourth generation (yonsei) Filipino nikkeijin, who are currently working in manufacturing plants and factories in Aichi Prefecture, Japan.
\end{abstract}

Keywords: Filipino nikkeijin, sansei, Filipino migration, identity

\section{Introduction}

As globalization compels nation-states to open their borders for human mobility, some nations still adhere to the notion of exclusivity and rejection of 'the foreign'. One interesting case is Japan, an economic giant whose industries urgently demand foreign labour. In spite of the numerous legislations to support migrants and encourage the spirit of multiculturalism, Japan still considers itself an ethnically homogenous country and has accepted only a limited number of foreign workers in recent decades. For this reason, Vogt (2013) warns that Japan's migration policies, which are a reflection of the state's indecisiveness and isola- 
tionist tendencies, are likely to fail in the long run. Green and Kadoya's recent study (2015) stresses the importance of contact and conversation between foreigners and locals; yet, evidently, such avenues of communication are very limited within the country.

While international migration has had a tremendous impact on cultural and ethnic identities, its effects vary on the socio-economic and political standing of both the host and accepting societies. Moving to a less familiar location, a migrant has to undergo a complex process of acculturation that entails changes in cultural identity, a process which has impacts on wellbeing and personal identity (Schwartz, Montgomery and Briones 2006). The course of adjustment is contingent on the interaction of components such as the characteristics and preferences of immigrants, the attitudes of members of the host society, national and local policies, and the prevailing attitudes in the immediate surroundings of the immigrants (Phnney, Horenczyk, Liebkind and Vedder 2001).

This article aims to address two important questions: First, how do Filipino nikkeijin assert and modify their national and ethnic identities during the experience of migration to their ancestral homeland? Second, why does bordering occur during the experience of dislocation? Past studies suggest that the experience of transnational migration strengthens nationalized ethnic consciousness. This study, however, highlights the exclusivist ethnic borders within and also beyond national identities that are created and modified depending on the underlying social, political and economic challenges confronted by the migrants.

As demonstrated by a study of a nikkeijin group from Brazil, migration can produce a form of deterritorialized nationalism in which 'national loyalties are articulated outside the territorial boundaries of the nation-state' (Tsuda 2003: 145). Migration, according to Takeyuki Tsuda, reveals 'one of the ironies of nationalism: it is precisely physical absence from the nation-state that enables national sentiments to be intensified, enhanced, and articulated' (Ibid: 156). Focusing on the identity shifts within the factory experience of the Philippine nikkeijin, this article reflects on Tsuda's theoretical insights to highlight the differences in the case of Philippine nikkeijin, who are shaped by multiplicity and fragmentation of identity.

This study examines the narratives of 60 Filipino nikkeijin who are working in Japanese factories in 2011 to 2013. The research participants were recruited from three religious institutions (Catholic, Evangelical, and Iglesia ni Cristo) in Nagoya. The research site, Aichi Prefecture, is host to global companies specializing in aerospace, precision ceram- 
ics, electronic equipment and the automotive industry. Because of the vibrant industries in the area, Aichi remains one of the preferred destinations of nikkeijin and other foreign workers in Japan. The interviewees were composed of third and fourth generation nikkeijin from various parts of the Philippines. While most of the interviewees have had a college education, their poor proficiency in Japanese language prevented them from exploring other job opportunities. Majority of the interviewees are currently working in medium or large-sized factories, which they call 'kaisha' (the literal translation of the Japanese term kaisha is corporation or company).

\section{The Politics of Migrant Bordering}

Identities set borders of inclusivity and exclusivity, thereby separating 'us from them'. Tilly and Tarrow state that identities have four components: (1) a boundary separating me from you or us from them; (2) a set of relations within the boundary; (3) a set of relations across the boundary; and (4) shared understandings of the boundary and the relations (2007: 79). People create collective understandings about the boundary, which eventually become culturally embedded. As in the case of my respondents, boundaries seem to be fluid and dynamic as they are defined by multi-layered self-identities and consciousness.

Boundaries have social and symbolic dimensions, which are closely related and intertwined. Sanders focuses on ethnic boundaries which he defines as 'patterns of social interaction that give rise to, and subsequently reinforce, in group members' self-identification and outsiders' confirmation of group distinction' (2002: 327). Symbolic boundaries are 'conceptual distinctions made by social actors to categorise objects, people, practices, and even time and space' (Lamont and Molnar 2002: 168). Such boundaries produce feelings of belongingness or difference and rejection from a certain group. Lamont and Molnar stress that this type of symbolic boundary is a significant medium through which social actors acquire status and resources.

Past studies also reveal the dynamics of symbolic boundaries in producing and structuring social inequality. Within the arena of migration scholarship, Furseth (2011) focused on religious teachings as framer of identities, hence the symbolism inherent in the wearing of hijab and the boundaries of inclusion and exclusion that it represents. To examine the symbolic boundaries manifested in the migrant discourses of nikkeijin, I employed Bail's (2008) proposition of focusing on the configuration 
of multiple symbolic boundaries (e.g. race, religion, language, cultural or human capital) instead of being limited by in-group or out-group categorizations. Bail posits that:

[B]y examining the entire configuration of symbolic boundaries, one can identify how the social boundaries previously protected by race are renegotiated. In this way, the boundary-work literature attempts to explain why majority groups choose certain symbolic boundaries, incorporating some groups while excluding others. (2008: 39)

Bail's research, like this study, sought to reveal the salience of multiple boundaries along with the assertion and negotiation of identities. Such boundaries are strategically reinforced and negotiated in order to obtain social rewards and resources.

\section{Filipino Migrants and the Nikkeijin in Japan}

The Filipino nikkeijin are the descendants of Japanese nationals who migrated to the Philippines between the late 19th century and 1945. On its website, the Embassy of Japan in Manila states that a nikkeijin visa can be granted to the 'children of Japanese nationals born on or before the end of World War II (referred to as the 2nd Generation), the 2nd Generation's descendants and their spouses'. ${ }^{1}$ Those possessing a nikkeijin visa are allowed by Japanese law to explore various employment opportunities in Japan without the usual restrictions imposed on foreign nationals.

By virtue of the 1990 Immigration Law, nikkeijin up to the third generation (sansei), as well as their spouses and children, were given a teijüsha visa (long term resident visa), which allows them to stay in Japan for one year, with unlimited renewals thereafter. This opportunity is granted to Japanese descendants 'on the qualification of a certain level of blood relations with Japanese' (Sharpe 2010: 359). From the perspective of the Ministry of Justice, the return migration of nikkeijin was the perfect solution to resolve the crippling manpower problem faced by several industries. This is because nikkeijin are Japanese descent co-ethnics; they are 'not socially and ethnically disrupting like other foreign workers (Tsuda 2010: 627).

Another relevant aspect of this policy revision is the permission granted by the government to nikkeijin labourers to perform unskilled jobs for which other foreigners were not eligible. This policy was grounded on the belief that 'the nikkeijin would fit in better with Japanese society' given their ancestral ties and cultural proximity (Rebick 2005: 
160). The crafters of the 1990 policy claim that the descendants of the Japanese, no matter where they come from, possess certain qualities that are compatible with the ways of life in Japanese society. As a result of the policy amendment, the nikkeijin have emerged as the largest group among foreign workers. The nikkeijin population currently residing in Japan is approximately 400,000, one of the biggest newcomer groups in Japan (Ohno 2008: 5).

Clearly, nikkeijin are entitled to better opportunities and compensation packages as compared to other Filipino migrants in Japan. Being fully documented, they are 'in limited supply and great demand' (Rebick 2005: 163). In contrast, the entertainers, -traditionally called 'Japayuki'2 - who were most numerous among Filipino migrants in Japan in the 1980s and 1990s were allowed to stay for a maximum of six months, and Filipinos in other industries or sectors such as construction, manufacturing and agriculture may have longer contracts, but employment restrictions hinder them from staying in Japan for a long period of time. In short, as co-ethnics of Japanese, the nikkeijin 'have better prospects in the labour market and indeed obtain the best employment packages for foreigners' (Shipper 2008:30). Although they have limited political and civic rights, most of them have access to medical care and public health services. In spite of their good educational background, it is evident that nikkeijin fail to experience career mobility as most of them remain in Japanese factories for lengthy periods of time. Regarding their salary, my interviewees earned JPY 151,000-200,000 per month, inclusive of overtime pay. These salaries, described by my interviewees as 'unsatisfactory', are significantly lower than they were in the 1990s. Being temporary or contract workers, most of these factory workers do not enjoy stable employment conditions (Ohno and Iijima 2010).

Contrary to the prevailing belief that these descendants would integrate more easily due to their ethnic background, empirical evidence suggest resistance and counter-identities (See Tsuda 2003) as typical responses to the experience of dislocation. Arguing that nikkeijin eventually increase their social embeddedness in Japanese society, Tsuda noted that long-staying Japanese Brazilians have become more socially involved with the Japanese as they increase their participation in the surrounding community (1999). In contrast to the case of the Brazilians, there are no indicators of increased social involvement and integration of Filipino nikkeijin to the Japanese community. What the narratives highlighted was the increased involvement in churches, Filipino groups, and informal gatherings of Filipino nikkeijin. Clearly, Filipino nikkeijin 
experience better living and working conditions than other Filipino migrants; but where do Filipino nikkeijin stand in relation to the ethnic groups of nikkeijin from other countries?

In a nationwide survey conducted by Ohno and Iijima (2010), nikkeijin respondents identify themselves as Filipinos, whereas only a quarter see themselves as Japanese. Similarly, the respondents of my study assert their Filipino consciousness through various mechanisms. First, they think that being born, raised and educated in the Philippines has made them more Filipino than 'nikkei' or Japanese. The Philippines, for them, is the only homeland where they wish to permanently reside. Second, the presence of their family and kin members in Japan has sustained their identity as Filipinos, and sometimes hindered their chances of developing their Japanese cultural identity. While some of them had expected that their temporary sojourn would allow them to develop a kind of Japanese ethnic consciousness, there was no venue in which to improve their Nihongo and discover more facets of the Japanese lifestyle because they exist within a Filipino social environment. Third, they talked about their 'connectedness' to the Philippines. They are emotionally and virtually connected to the Philippines through mass media and the cyber world. There was no escape from the daily news, both positive and negative. This made them nostalgic and have affected their nationalistic sentiments.

One manifestation of attachment to a feeling of national collectivity is when Filipino nikkeijin support their compatriots during times of distress and mistreatment. At these times the nikkeijin exhibit 'deterritorialised nationalism' to support their countrymen and lambast those who mistreat the Filipinos. One respondent, Mr George, commented:

That's why when I hear some negative things about the Philippines, I feel hurt. No matter if it's true or not, I feel offended when they say bad things about the Philippines and the Filipinos. ${ }^{3}$

One interesting case is the unequal treatment of Brazilian nikkeijin and Filipino nikkeijin. 'They prefer Brazilians over Filipinos,' said George, a descendant with a grandmother from Tokushima-ken. George believes that the Brazilians receive compensations higher than the Filipinos receive, despite the fact that their workload is heavier than the Brazilians'. Filipino nikkeijin argue that they receive different treatment in terms of salary, benefits, workload and overtime opportunities. Similarly, Brenda highlighted the workload injustice:

I noticed that if you [a Filipino nikkeijin] are working in a line with easier tasks, the manager will reassign you to a section with heavier work. Brazilians 
would be given the easier task that you used to do. Unfair, right? If you complain, they will bully you. Chances are, they [line managers] won't give you overtime. ${ }^{4}$

In Brenda's narrative, it is the Japanese managers who designate tasks in such a way that Brazilians get the easier time. Although Filipino nikkeijin feel the inequity, they tended to stay silent to avoid confrontations that could have other negative consequences.

The cases mentioned above illustrate how Filipino nikkeijin sympathize with their countrymen in times of distress. In their shared experience of dislocation and marginalization, Filipinos feel the commonality of their predicament, thereby strengthening self-identification and nationalistic fervour. In multi-ethnic workplaces, Filipino nikkeijin create an ethnic border that separates them from the other ethnicities while uniting them as a deterritorialised community of Filipinos. However, identity shifts to different dynamics if we analyse the social relations within Filipinos in their respective work places. As I will discuss later, layered borders are knitted within the confines of the Filipino ethnic boundaries, and subtle confrontations and ethnic clashes occur on a range of levels.

\section{Regionalistic Solidarities and Differences}

The previous section highlighted the tendency for nikkeijin to create an exclusive ethnic zone composed of Filipino migrants who support each other in times of distress and uncertainty. However, while all the interviewees implied that they were more comfortable with fellow Filipinos (both nikkeijin and non-nikkeijin), this preference warrants further analysis. The following sections illustrate how ethnic borders are 'recreated' within the separate niche of Filipino nationals abroad. The narratives illustrate how identities undergo 'decentring' as conflicts within the workplace ignite inter-ethnic clashes and regionalistic solidarities.

\section{Stereotyping and Ethnic Attribution}

The Philippines' National Commission for Culture and the Arts pointed out that the Filipino ethno-linguistic groups, even though they co-exist harmoniously, exhibit friction in various situations. Historically, ethnic wars had occurred and peace pacts had been made in order to restore peace. Undoubtedly, bordering reinforced regionalistic identities. The official webpage of the office highlighted the maintenance of bordering:

Ethnic boundaries, however, are continually maintained although transactions take place through them. Interchanges among the different 
Philippine ethnic groups are not entirely harmonious as frictions develop even among the best of kin. When kin groups are involved, friction escalates in accordance with the number of participants and intergroup conflicts taking place. More often than not blood flows which must be balanced by each contending side. (National Commission for Culture and the Arts 2011) ${ }^{5}$

In this study, 34 interviewees mentioned that ethnicity-based stereotypes did not matter when they were still working in Manila. However, when they migrated and entered the factory in Japan, nikkeijin tended to be closer to their particular regionalistic group-Bisayan, Ilocano, Tagalog, Kapampangan or Bicolano-such that the known ethnicitybased stereotypes began to be noticed and highlighted. A leader of one religious group said:

I'm wondering why simple misunderstanding escalates to violent fights. I witnessed how they fight in kaisha - fist fights... very violent, that can lead to a bloody outcome. In the Philippines, regionalistic bickering is usually limited to stereotyping and exchanges of harsh words... but here, they [physically] hurt each other. They can really kill each other. ${ }^{6}$

Clashes often occur among the dominant groupings, usually between Ilocanos and Bisaya, or Tagalogs and Bisaya. ${ }^{7}$ These conflicts usually have their roots in an ethnic attribution of a certain negative attitude. For instance, six interviewees from Davao believed that Luzon-based nikkeijin (specifically those who grew up in Manila) looked down on nikkeijin and other Filipinos who came from the Bisayan and Mindanaon islands. Hence, they think that these nikkeijin from Manila are boastful and arrogant. Joy shared her experience:

The majority of those nikkeijin from Manila are too proud of themselves. I have this workmate from Manila, and I heard how she cursed him [Joy's friend]. She said: 'You're stupid. Stay in the mountains where you belong'. So, is it because he came from Mindanao, or Davao, [that made her say that] he belongs in the mountains? I was silently laughing... because actually, it's pretty obvious that those people from Mindanao are better educated than her. And I'm sure that my friends from Mindanao are better off than her. ${ }^{8}$

And Vina from Baguio also shared some sentiments against Bisayans:

I know there's always a conflict between Ilocanos and Bisayans. I have an Ilocano background, but I never believed that the conflicts were true until I came here to Japan. The real problem is, we have no sense of unity. Selfishness. Bisayans have their own group, and they support each other in front of the leader... But they just support themselves... I haven't received any help from them. When there's an opportunity for overtime, they take it all... for themselves. Being so selfish. ${ }^{9}$ 
These narratives present diverging reasons for the ethnic clashes within the Japanese factories. Stereotyping is clearly a contributing factor, with perceptions of other ethnic groups becoming intensified through the experience of migration. Another reason relates to communication channels, specifically language issues.

\section{The Politics of Language}

Historically, the designation of the national language had been a fierce battle among the various ethno-linguistic groups in the Philippines. Remarkably, the Bisayans had waged a legal war against the propagation and mode of standardisation of Tagalog. In the end, the Filipino language, which is primarily based on Tagalog, was selected as the 'Manila Lingua Franca'. This has caused various controversies about the marginalization of other regions and provinces, and the proliferation of the negative perceptions against the 'Imperial Manila'. However, in reality, the teaching of Filipino as a national language is 'for symbolic purposes and not for purposes of utility' (Gonzales 2000:7).

At present, Tagalog is still the most widely spoken language in the archipelago. With hundreds of ethnic groups scattered around the country, there are around 150 languages and dialects actively spoken in the Philippines. The major languages include Tagalog, Cebuano (also known as Bisaya), Ilocano, Hiligaynon (also known as Ilongo), Bicolano, Waray and Kapampangan. ${ }^{10}$ However, Tagalog remains the primary language in the capital city of the Philippines, and there is a bias towards learning and using the language of the metropolitan rather than regional languages. Fe, a female respondent from General Santos City, talked about this language politics:

I was a teacher in the Philippines. I earned the respect of our countrymen for being a teacher. But these people from Manila, or maybe somewhere from Luzon, think that my Bisayan accent indicates stupidity. My accent implies that I was born in the Bisayan area, but I am still a Filipino, and they have no right to ridicule me, or say bad things to me like 'stupid'. ${ }^{11}$

At the other extreme, nikkeijin who were born and raised in Manila or Northern Luzon think that the Bisayan nikkeijin are exclusivist and gossipers. As previously mentioned, the common complaint is their use of the Bisayan language, regardless of the presence of other Filipinos who cannot understand it. Many Tagalog-speaking nikkeijin consider Bisayan nikkeijin to be insensitive and rude. 
The various ethno-linguistic groupings are often attributed with a particular social status. Nikkeijin from rural provinces are usually perceived as poor and uneducated folk, a perception that does not necessarily reflect the reality (see Vilog 2013). In fact, most of the interviewees from the Southern Philippines had had decent work in the Philippines before migrating to Japan. While some nikkeijin did not finish college, a significant number were able to obtain a university diploma. ${ }^{12}$

Despite these factors, most verbal confrontations that take place inside the factory are caused by personal issues that are not related to ethnolinguistic differences. However, when conflicts arise, fellow nikkeijin from the same province eventually become involved as they try to support their comrades. In effect, simple personal squabbling becomes an ethnolinguistic/regionalistic enmity inside the factory.

When interviewees were asked about the reasons behind factions and conflicts, the most common theme of the narratives centred on their opponents' lack of education. Even the ability of speaking English is commonly considered as a factor. Teresita from Davao mentioned that most workers from her province were not able to attend school due to poverty when they were young. Thus, their 'socializing skills' are very low. In contrast to the Bisayans, those who resided in Baguio and other areas close to the US bases have the considerable advantage of speaking English. This ability gives them confidence and many feel that 'they dominate the community'. Echoing the grievances of other Bisaya, another Bisaya, an interviewee named Bernadette, expressed how she was offended by various street words that other Tagalog nikkeijin use, like 'bobo', 'tanga' and 'gago' - all of which refer to stupidity. She believes that these words are only used by 'unrefined and uneducated people'. But for Annie, a Tagalog, it is not only the Bisayan nikkeijin who use those words; Tagalogs and Ilocanos have their own expressions that offend other workmates. The usage of such cruel words escalates tension between groups.

Nikkeijin who were born and raised in Manila or Northern Luzon tend to think that the Bisayan nikkeijin are exclusivist and gossipers and, as noted, many Tagalog speakers consider Bisayan nikkeijin to be insensitive and rude. Candice has an interesting account of her first job experience:

I used to work in this factory of wires. It was such a bad experience, really. Almost everyone was Bisaya, and they were usually talking about me. I can't understand them! My dad is Ilonggo, but we grew up in Quezon City. I used to ignore them whenever they did that to me, but I felt offended 
when they called me the 'Tagalog lady'. I heard them gossiping about this 'Tagalog lady'... 'She's like this, and like that!' I was emotionally tortured, so I resigned from that company after a few days. ${ }^{13}$

Although Tagalog, Cebuano/Bisaya and Ilocano lead the list of major languages and dialects, the groupings in the kaisha are not strictly defined according to these language groups. If a nikkeijin has no co-worker from the same province, they will fluidly affiliate themselves to the group with the closest linguistic and cultural resemblance to them.

Besides education, financial or economic status is also an agitating issue among the nikkeijin. Surprisingly, the topic of financial status was generally brought up by younger interviewees of age 25 and below. Responding to the question on the causes of conflicts, they argued that Luzon-based nikkeijin think that they (Bisayans in this case) belong to the 'poorest of the poor'. Jeff claimed:

Before they criticize others, they should look at the real situation. Okay, some of the people from Visayas and Mindanao came from very poor families. But now, they have survived because of hard work and perseverance. Instead of mocking them, why not be supportive to a fellow Filipino? ${ }^{14}$

From the point of view of Ced, a descendant who grew up in Manila, nikkeijin workers in their kaisha are generally 'between middle class and poor'. Having been a migrant worker for almost 15 years, Ced observed that Filipino nikkeijin are not generally destitute although there are some who were impoverished by their accumulated debts in the Philippines. Ced knows a few Filipino nikkeijin who are extremely poor, but not all of them are from the Southern region. Hence, he thinks that the Bisayans'accusation that Tagalogs see them as impoverished was merely a product of self-pity and illusion. While he thinks that some Tagalogs can be arrogant, he also remarked that it is not fair to generalize. Citing how stressful factory work is, Ced claimed that a migrant's emotional state can be affected by overworking in an environment that lacks adequate social support.

\section{Intersectionality and Bordering}

Filipino nikkeijin consciously or unconsciously create a border that differentiates them from other groups and assert an identity that matches the shared characteristics they have with the group that they associated themselves with. However, the projection of shared identity is more than situational, as migrants also use identity to gain access to resources and political power. The narratives above seemed to align with Nagel's (1994) 
position, which claimed that 'boundaries' designate ethnic categories, which are in turn attached to certain rewards or sanctions.

Having 'multiple identities' does not imply that each identity is asserted or relevant only in particular situations. It is more complex than that. The idea of 'intersectionality' is useful as it denotes the various ways in which other social categories (e.g. social class, gender, ethno-linguistic group, and degree of nikkei generation) intersect to shape and position the bordering zone reflects a migrant's identity. Intersectionality is a 'way of mediating the tension between assertions of multiple identity and the ongoing necessity of group politics' (Crenshaw 1991: 1296).

In spite of the deeply ingrained Filipino identity, there are tendencies towards fragmentation whereby ethno-linguistic or regionalistic ethnicity is accentuated and ethnic groupings become the source of security and belongingness during times of dislocation. Again, although they are identified as Filipino nationals, nikkeijin belong to different ethnic groupings, inevitably interacting within the workplaces and social spaces of Filipino nationals. Boundary-making is a standard part of interaction. As Barth noted, there would be 'criteria and signals for identification... and a structuring of interaction which allows the persistence of cultural differences' in such cases of inter-ethnic contact (1998: 16). Fragmentation also involves criticism of fellow Filipinos, or rejection of the 'others' within the Filipino community.

\section{Identity Fragmentation and Kaisha Politics}

Why do Filipino nikkeijin tend to cluster into exclusive groups, criticize other groups, and assert their differences from the 'others'? The 'otherness' constructed by Philippine society in the everyday process of meaning-making and socialization within the bounds of the nation-state has been transmitted by the migrants themselves and reproduced as they experience the impact of deterritorialization. While regionalistic prejudices have been brought to the host society, I argue that power relations and politics within the kaisha further solidify regionalistic groupings and ignite deeper conflicts among the regionalistic clusters.

But how does marginalisation, as expounded in the narratives above, transform into empowerment through identity decentring/shifting? Empowerment, in its broad sense, is defined as 'the process whereby individuals achieve increasing control of various aspects of their lives and participate in the community with dignity' (Lord and Hutchison 1993). In the context of this study, empowerment indicates an increase 
in the workers' control over their limited resources, while preserving a sense of dignity in their labour.

While the stereotyping of rival ethnics or marginalized groups is a daily reality not only in the Philippines but also in other countries, these inter-group rivalries and contestations intensify in the confines of a Japanese factory. As one of the interviewees pointed out, regionalistic tendencies have become offensive and violent within the kaisha, stirring confrontations, both verbal and physical: 'events that you don't really see in Manila or in other metro places'. These kinds of confrontations are not frequently witnessed in the religious spaces and other venues of the Filipino community in Japan. Why, then, does it intensify in the kaisha? I argue that there are political contestations embedded in the power relations that shape the social environment of the kaisha. Asserting regionalistic identity is a strategy to compete for political opportunities and power.

\section{Ethnic Solidarity as Access to Resource Allocation}

Ethno-linguistic groups of Filipinos in Japan are composed of kinship and geographically based networks and ties, which were established prior to or during the process of migration. The mode of communication (since they speak the same regional languages) facilitates easy interaction and development of new social ties. Frequent interaction grows into 'trust networks', which eventually become an effective expression of ethnic solidarity.

As previously described, the kaisha is a modern hub of assembly and production lines. The labour force is disempowered as they are treated like machinery in the production process. To heighten the experience of marginalization, the collected narratives also highlighted the politics arising from the economic reality of limited resources awarded to a select few by the Japanese management. Roberson noted in his ethnographic study of Japanese factory workers that there are cases in which the management is 'able to exercise its judgment regarding promotions more freely and flexibly, based on evaluations of company needs, the individual employees' attributes, and more personalistic considerations' (1998:61). My interviewees also mentioned cases of patronage, power play, and bullying in management-labourer and labourer-labourer relations.

For instance, interviewees mentioned the competition for overtime slots. Working overtime significantly increases the hourly rates accumulated by each factory worker. However, not everyone has the opportunity to do overtime. As companies adjust their production 
targets during crisis periods, the supervisors and managers have to choose those workers who are known for their efficiency and work ethic. While the selection policy should be based on the principle of meritocracy, the actual practice of selection is based on power relations: patronage and ethnically-biased selection. A Bisayan interviewee mentioned in her narrative that 'it is the Tagalog group that always asserts their superiority [they do it] to please their manager and make themselves more appealing (mabango) to the management'. The interviewee admitted how she took offense of this behaviour, and said that Bisayan workers were also 'proving their worth' to the management. ${ }^{15}$ This narrative implies that Bisayan solidarity has strengthened because of their collective repugnance to the Tagalog group. The interviewee has also revealed that the group informally discusses their grievances against the Tagalog group. When asked what they usually do in response to the intimidation of the Tagalog group, the replies ranged from: 'We ignore them' (Susan); 'We make sure that we work harder... and we don't fight back' (Elmo); to the more aggressive 'Oh, sige lang, bring it on'! (Marissa).

The line manager, who decides on matters of overtime, labour wages and benefits, is usually seen as an authoritative figure in the factory line. However, he is also dependent on the unity and support of the workers in order to achieve the line's target output. It is important for him to satisfy the demands of the dominant groups along the assembly line; if not, the workers may disrupt the production processes. His decisions on overtime slots and other resource distribution are highly influenced by the dominant groups of the kaisha.

Work politics is inevitable in every workspace, and it can affect not only internal employee relations but also the general work attitude, job performance and organizational citizenship behaviour (Randall, Cropanzano, Bormann and Birjulin 1999). The interesting dynamics found in this study reveals the struggle to pursue self-interest by mobilizing support from co-ethnics, hence the paradox of kaisha politics. The fracturing effects of organizational politics are essentially reinforcing solidarity among co-ethnics based on ethno-linguistic membership.

\section{Regionalistic Solidarity as Source of Social Capital}

Regionalistic solidarity serves as a support and networking mechanism for accessing resources within and beyond the kaisha. Through these networks, nikkeijin are connected to the gatekeepers of the labour market 
who provide information and access to a more financially and socially rewarding workplace.

Social capital is established by the 'trust networks' operating within a group. Trust, as a social principle, and especially in the case of the Filipino nikkeijin workers, is created and reinforced by repetitive social interaction. Trust is clearly prevailing and highest among those who share the same physical features and culture, while the most distrusted are those with a different appearance and unknown practices (Pye 1999). In the case of Filipino nikkeijin, the similarity of regional language, familiarity of geographical location in the Philippines, and the kinship networks embedded in the regionalistic grouping are the key factors that intensify 'trust'. While Filipino values and culture remain intact in the Filipino community, the tendency to constantly interact with those who speak the same language, and exclude those who don't, gradually fragments the national collectivity. Mutual trust is established within the inner circle of the group, usually composed of comrades from the same ethno-linguistic cluster (see Goulbourne and Solomos 2003).

To add another layer, since they are hired through kansetsu koyō (indirect employment), Filipino nikkeijin have been heavily dependent on their labour brokers. However, many long-stayers have already realized the benefits of being directly employed without the assistance of their brokers. Moving away from the broker is a serious risk for a nikkeijin labourer given that the broker serves as the job finder, provider of medical support in times of sickness or accident, guarantor for apartment rentals, job finder for relatives who are still in the Philippines and intend to migrate to Japan, and communicator or translator for company chiefs. While brokers can be helpful, many take an unfair percentage from the salary of the nikkeijin worker.

If a nikkeijin decides to move away from his/her broker, the social relationships developed within their regionalistic group become the primary source of information and support (e.g. transferring to a better job). Comrades from the same group help each other to explore better labour markets, looking to the networks where their friends or kin members are working. It is this practice of 'introducing someone' (shōkai) to the prospective company that establishes a stronger bond, considered a utang na loob (debt of gratitude). Utang na loob becomes a seal of loyalty to the person or group that supported the worker. One must return the favour to the in-group persons who helped the worker, thereby further strengthening the bonding of the group. Thus, within the social setting of a kaisha where resources and power are contested, 
the bonds of comradeship, sealed by their debt of gratitude to one other, become the solidifying force that unifies the in-group while excluding the others.

\section{Regionalistic Solidarity as Assertion of Dominance}

A mechanism known as exclusionary closure 'occurs when immigrants provide privileged access to jobs and mechanisms for training to their own group, while excluding those not in the ethnic group' (Parkins 1979, cited in Cranford 2005). One local government staff member of a certain Prefectural Office recalled receiving complaints from the Bisayans about the 'orchestrated efforts' of the Tagalog groups to filter entry to the kaisha by preventing non-Tagalog Filipinos (whether nikkei or not) from obtaining jobs there, as well as bullying those Bisayans already employed there until they resigned. He said this type of conflict might be based on a 'deep-seated animosity among these ethno-linguistic groups'. His reasoning echoes the conventional wisdom that profound ethno-linguistic animosities are historically moulded. However, returning to the narrative of a nikkeijin from Davao who claimed that every regionalistic group wants to be 'dominant', it is reasonable to assume that exclusionary closure occurs here because the Tagalog group wanted to maintain their control in the workplace, and they viewed the Bisayans as a threat to their prevailing dominance.

Across the board, the interviewees explained that their preference for working with nikkeijin from their own region or province was based on language. Easier communication, for them, translates into a more comfortable working environment. Striving to accomplish their production goals, workers have no time for miscommunication and confusion. Working with a person speaking the same regional language means easier way of conveying instructions and messages, which all translates into better output, satisfied bosses, and receiving rewards, whether formal or informal. And when language becomes a main basis for forging social networks, the effects of the politics of language previously discussed cannot be undermined.

Exclusionary closure worsened during the initial period of the Global Financial Crisis. One local government official pointed out that many companies had either shut down or implemented massive lay-offs (haken-giri) of their workers. The factory management was charged with deciding who would leave and who would stay. The groupings described above served as support groups to lobby and influence man- 
agement decisions about redundancies. Group loyalty is again reinforced to strengthen influence over the decision-makers.

\section{Conclusion}

The phenomenon of ethno-linguistic bordering becomes more salient during the migrant experiences of Filipino nikkeijin, especially in a location or workplace where there are political and socio-economic contestations. Most people belonging to ethnic groups do not consciously identify with their groups and they are usually unaware of such groupings (Gracia 2005: 43), yet they create borders to separate those who seemed to belong to another ethnolinguistic zone. This article argued that ethno-linguistic boundaries are forged by mutual feelings of commonality and rivalry. The causes of such conflicts are multifaceted, starting from stereotyping, language barriers, socio-economic status, and even educational background. While the issues are diverse, it is evident that conflicts are fuelled by mutual animosity between the Tagalog nikkeijin or the Ilocano nikkeijin against the Southern Philippine nikkeijin (usually Bisaya), whose sentiments are generally affected by the perception of being marginalized by 'arrogant' and hegemonic groups. This study does not claim that this kind of bordering process is only experienced by Filipino nikkeijin. In fact, the phenomenon may also occur in the Philippines, and even among non-nikkeijin Filipinos in other lands. However, the narratives reveal that workplace politics in a Japanese kaisha seemed to contribute to the bordering process.

Examining the profound reasons that ignite conflict, I highlighted the role of factory politics in dividing Filipino communities and promoting groupism and rivalries. In a workplace where resources are being contested, ethno-linguistic groupings serve as the source of support and empowerment against rival groups that threaten to dominate them. This paper demonstrates how the nikkeijin community from the Philippines fails to unify their own nikkeijin group in Japan, but instead creates affiliations with their respective regionalistic comrades in various situations, not only because of issues related to stereotyping and ethnic attribution, but also because of the latent power struggle occurring in their workplace.

Finally, this article highlighted the fluidity and continuity of identity construction. Historical conjunctures have fortified an affiliation to the national collectivity, yet the experience of migration has challenged the pre-conceived self-identification of being a Filipino. Nikkeijin have viewed themselves as economic migrants rather than ethnic returnees 
and this investigation has seen the resistance of the Filipino nikkeijin to being categorised as ethnically Japanese, mindful of the cultural upbringing and positive meanings attached to being Filipino. A process of individual identity negotiation takes place when a nikkeijin leaves the homeland and enters the conflict-ridden world of Japanese kaisha, where forces of cultural pluralism, economic competition, and power politics fundamentally affect nikkeijin consciousness.

Ron Bridget Vilog is an Associate Professor at the International Studies Department of De La Salle University, Manila. He obtained his doctorate in International Development from the Graduate School of International Development, Nagoya University, Japan.Email: ron.vilog@dlsu.edu.ph

\section{NOTES}

1 Embassy of Japan in Manila, Philippines: http://www.ph.emb-japan.go.jp/visiting/new\%20visa/nikkeijin.htm. Accessed 10 January 2014.

2 While Filipino workers are scattered in the international labour market, it is only in Japan (in the 1980s to 1990s) where majority of the Filipino foreign workers belong to the entertainment sector (Yu-Jose 2007). These entertainers work as performing artists in Japanese restaurants and bars. Highly regulated by the Philippine government, this employment opportunity became highly popular among young Filipino women in the 1980s to early 1990s who wished to escape poverty in the Philippines.

3 Interview conducted in Nagoya, 5 June 2012.

4 Interview conducted in Nagoya, 8 June 2012.

5 National Commission for Culture and the Arts 2011. Intergroup Relationship. http://www.ncca.gov.ph/about-culture-and-arts/e-books/e-book.php?id=2\&t=2. Accessed 6 January 2013.

6 Interview conducted in Nagoya, 15 January 2013.

7 Some languages have closer affinity to another Philippine language (Dolan 1991). For example, an Ilocano-speaker can easily learn and understand the language of Pangasinan. Those coming from the Visayas area (Cebu, Ilongo and Waray) have different languages but they can easily communicate with each other using their own mother tongue.

8 Interview conducted in Nagoya, 5 October 2012.

9 Interview conducted in Nagoya, 10 November 2011.

10 About 90 percent of the population uses one of the major languages in the Philippines (Tagalog, Cebuano, Ilocano, Hiligaynon, Bicolano, Waray-waray, Kapampangan, and Pangasinan). These languages belong to the Malay-Polynesian language family (Dolan 1991). Partly due to geographical reasons and partly caused by historical consequences, ethno-linguistic groupings developed amidst the government's effort to unify the country. Diversity of languages has always posed as a challenge to achieve national unity.

11 Interview conducted in Nagoya, 5 October 2012.

12 The respondents of this study who have graduated from colleges and universities have diverse degree/ diploma: Education, English, Computer Science, Engineering, 
Veterinary Medicine, Commerce, and Accountancy. In this research, 38 respondents have college diploma, 7 attended vocational training, 9 are high school graduates, and 6 respondents were not able to reach high school.

13 Interview conducted in Nagoya, 8 November 2012.

14 Interview conducted in Nagoya, 5 October 2012.

15 Interview conducted in Nagoya, 8 November 2012.

\section{REFERENCES}

Bail, Christopher 2008. 'The Configuration of Symbolic Boundaries Against Immigrants in Europe'. American Sociological Review 73(1): 37-59.

Barth, Fredrik 1998. Ethnic Groups and Boundaries: The Social Organization of Cultural Difference. Illinois: Waveland Press.

Benmayor, Rina, and Andor Skotnes 2009. Some Reflections on Migration and Identity. In R. Benmayor and A. Skotnes (eds.) Migration and Identity. New Brunswick: Transactions Publishers: 1-18.

Cranford, Cynthia 2005. 'Networks of Exploitation: Immigrant Labor and the Restructuring of the Los Angeles Janitorial Industry'. Social Problems 52(3): 379-397.

Crenshaw, Kimberle 1991. 'Mapping the Margins: Intersectionality, Identity Politics, and Violence against Women of Color'. Standford Law Review 43(6): 1241-1299.

Dolan, Ronald (ed) 1991. Philippines: A Country Study. Washington: GPO for the Library of Congress. Available at http://countrystudies.us/philippines/.

Furseth, Inger 2011. 'The Hijab: Boundary Work and Identity Negotiations among Immigrant Muslim Women in the Los Angeles Area.' Review of Religious Research 52(4): 365-385.

Goulbourne, Harry, and John Solomos 2003. 'Families, Ethnicity, and Social Capital'. Social Policy and Society 2 (4): 329-338.

Gonzales, Andrew 2000. 'The Politics of Language: Language, Ethnicity, and Nationstate in the Philippines'. Asia Pacific Social Science Review 1(2): 1-13.

Gracia, Jorge 2005. Surviving Race, Ethnicity, and Nationality. Lanham, Maryland: Rowman and Littlefield Publishing, Inc.

Green, David and Yoshihiko Kadoya 2015. 'Contact and Threat: Factors Affecting Views on Increasing Immigration in Japan'. Politics and Policy 43(1): 59-93.

Lamont, Michele and Virag Molnar 2002. 'The Study of Boundaries in the Social Sciences'. Annual Review of Sociology 28:167-195.

Lord, John and Peggy Hutchison 1993. 'The Process of Empowerment: Implications for Theory and Practice'. Canadian Journal of Community Mental Health 12(1): 5-22.

Nagel, Joan 1994. 'Constructing Ethnicity: Creating and Recreating Ethnic Identity and Culture'. Social Problems 41: 152-176.

Ohno, Shun 2008. 'Transnational Citizenship and Deterritorialized Identity: The Meanings of Nikkei Diasporas' Shuttling Between the Philippines and Japan'. Asian Studies 44(1): 1-22.

Ohno, Shun and Mariko Iijima 2010. Citizenships, Lives and Identities of the Philippine Nikkeijin Residing in Japan: Reports on the Results of a Nationwide Questonnaire Survey. Fukuoka: Kyushu University Asia Center.

Phinney, Jean, Gabriel Horenczyk, Karmela Liebkind, and Paul Vedder 2002. 'Ethnic Identity, Immigration, and Well-Being: An Interactional Perspective'. Social Issues 57(3): 493-510.

Pye, Lucian 1999. 'Civility, Social Capital, and Civil Society: Three Powerful Concepts for Explaining Asia'. Journal of Interdisciplinary History 29(4): 763-782. 
Randall, M., Cropanzano, R., Bormann, C., and Birjulin, A. 1999. 'Organizational Politics and Organizational Support as Predictors of Work Attitudes, Job Performance, and Organizational Citizenship Behavior'. Journal of Organizational Behavior 20:159-174.

Rebick, Marcus 2005. The Japanese Employment System: Adopting to a New Economic Environment. New York: Oxford University Press.

Roberson, James 1998. Japanese Working Class Lives: An Ethnographic Study of Factory Workers. New York: Routledge.

Sanders, Jimy M. 2002. 'Ethnic Boundaries and Identity in Plural Societies'. Annual Review of Sociology 28: 327-357.

Schwartz, Seth, Marylyn Montgomery and Ervin Briones 2006. 'The Role of Identity in Acculturation among Immigrant People: Theoretical Propositions, Empirical Questions, and Applied Recommendations' Human Development 49:1-30.

Sharpe, Michael 2001. 'What Does Blood Membership Mean in Political Terms? The Political Incorporation of Latin American Nikkeijin in Japan, 1990-2004'. Japanese Journal of Political Science 12(1): 113-142.

Shipper, Apichai 2008. Fighting for Foreigners: Immigration and its Impact on Japanese Democracy. Cornell University Press: Ithaca, US.

Tilly, Charles and Sidney Tarrow 2007. Contentious Politics. Paradigm Publishers: Boulder, Colorado.

Tsuda, Takeyuki 1999. 'The Permanence of Temporary Migration: The Structural

Embeddedness of Japanese-Brazilian Immigrant Workers in Japan'. Journal of Asian Studies 58:687-722.

Tsuda, Takeyuki 2003. Strangers in the Ethnic Homeland: Japanese Brazilian Return Migration in Tansnational Perspective. New York: Columbia University Press.

Tsuda, Takeyuki 2010. 'Ethnic Return Migration and the Nation-State: Encouraging the Diaspora to Return Home'. Journal for the Association for the Study of Ethnicity and Nationalism 16(4): 616-636.

Vilog, Ron Bridget 2013. 'Layered Migrant Identities: The Case of Filipino Nikkeijin Workers in Japan'. International Journal of Humanities and Social Science 3(13): 128137.

Vogt, Gabriele. 2013. 'When the Leading Goose Gets Lost: Japan's Demographic Change and the Non-Reform of its Migration Policy'. Asian Studies: Journal of Critical Perspectives on Asia 49(2): 14-44.

Yu-Jose, Lydia. 'Why are Most Filipino Workers in Japan Entertainers?:

Perspectives from History and Law'. Kasarinlan: Journal of Third World Studies 22(1): 61-84. 